\title{
ORTEGA Y GASSET, A VIDA COMO REALIDADE METAFÍSICA
}

\author{
José Mauricio de Carvalho
}

\begin{abstract}
RESUMO: Neste artigo, estudamos as características que o filósofo espanhol Ortega y Gasset atribuiu à vida. Mostramos que o essencial de sua meditação girou em torno do assunto. No entanto, o tema ganhou densidade metafísica somente no final dos anos 1920, quando suas consideraçóes foram inseridas na tradiçấo filosófica do ocidente. Foi quando ele apontou a insuficiência do realismo e do idealismo na abordagem do fundamento pretendido pela Filosofia e apresentou a filosofia da razáo vital como um passo adiante das duas grandes perspectivas filosóficas que marcaram a história da metafísica.
\end{abstract}

PALAVRAS-CHAVE: Vida. Metafísica. Características. Realidade. Circunstância.

\section{CONSIDERAÇÓES INICIAIS}

1. A Metafísica é disciplina filosófica, que a tradição reconhece como a mais importante, autônoma e fundamental, entre elas. O seu propósito é apontar o fundamento geral que sustenta o homem em meio à sua experiência do mundo e dos riscos de viver. Nesse sentido, a Metafísica espera propor verdades suficientes, isto é, que não dependam de outras para se sustentar e, ao contrário, porque se referem à totalidade do saber possível, sirva às outras verdades de suporte ou fundamento. Esse conceito remonta a Aristóteles, que, no livro de Metafísica, a define como a ciência das primeiras causas e princípios fundamentais. $\mathrm{O}$ mundo moderno concebeu uma outra visão de Metafísica, entendida como Gnoseologia. Sua expressão amadurecida foi obra de Emmanuel Kant, mas sua origem pode ser antevista no projeto de Francis Bacon, o qual esperava criar uma nova ciência universal que fosse a base de todas as outras.

2. Durante o século XIX, a meditação filosófica tratou a Metafísica como um saber crepuscular, compreensão concebida pelo filósofo alemão

\footnotetext{
${ }^{1}$ Psicólogo, Pedagogo e Filósofo, com especialização em Filosofia e Filosofia Clínica, Mestrado e Doutorado (1990) em Filosofia, com estágios de Pós-Doutoramento na Universidade Federal do Rio de Janeiro (2002) e Universidade Nova de Lisboa (1994). Professor Titular de Filosofia Contemporânea do Departamento de Filosofia da Universidade Federal de São João del-Rei, membro do Instituto Brasileiro de Filosofia (SP), do Instituto de Filosofia Luso Brasileira (Lisboa), da Academia de Letras de São João del Rei e da Academia Mantiqueira de Filosofia. E- mail: mauricio@ufsj.edu.br
} 
Georg Hegel. O sistematizador do idealismo absoluto afirmava que a Filosofia somente entra no cenário cultural quando os outros aspectos que o constituem já se encontram consolidados. A célebre alegoria da coruja de Minerva, que só alça voo ao entardecer, traduz o entendimento de que o filosofar é tardio, quando comparado a outras criaçôes culturais. Nessa visão hegeliana, a Filosofia entra num cenário já pronto, toma consciência das coisas, mas não se pronuncia sobre o que elas devem ser. $\mathrm{O}$ seu conteúdo é o que se produz no domínio do espírito, que, segundo Hegel, se encontra objetivado no mundo exterior e na intimidade da consciência.

3. Além desse aspecto, o filósofo alemão entende que a consciência é histórica, o que no idealismo absoluto significa que o saber fundamental não é alcançado pelas teorias do início da tradição filosófica. Para Hegel, a meditação filosófica alcançara com o idealismo absoluto a maturidade, sua filosofia era fruto do evolver do Espírito em dois mil e quinhentos anos de História, num processo que ganha densidade no tempo, como um rio que ganha importância à medida que recebe seus afluentes.

4. O resultado dessa compreensão, a saber, o surgimento tardio da Filosofia e a consciência histórica da verdade, apontam para certezas ou verdades parciais que não ficam completas nos sistemas construídos no decorrer da história da filosofia, pelo menos até o coroamento do processo no idealismo. A rejeiçáo do papel final desempenhado pelo idealismo absoluto, porém, desconsiderar as outras conclusões de Hegel, significa compreender que a missão da Filosofia é buscar a verdade. $\mathrm{O}$ que foi admitido como certeza universal num certo tempo, mostra-se insuficiente com as andanças da história. Enfrentar as mudanças da história com uma proposta definitiva é missão impossível, porque é necessário formular sobre a realidade uma teoria evidente e é nesse ponto que o projeto de certeza universal revela seu ponto frágil. Aspectos tidos por evidentes num momento histórico não são aceitos em outros. A perda da evidência provoca a desconfiança nos princípios admitidos, restando o desafio de refazer as concepçóes antes tidas como verdadeiras. Assim revisadas, as sucessivas teorias da realidade elaboradas na história da metafísica são muito menos contribuiçóes complementares que sucessivas retomadas da razão universal ${ }^{2}$. Por outro lado, as teorias metafísicas só ficam claras quando devidamente contextualizadas.

\footnotetext{
${ }^{2}$ A revisão crítica da filosofia da história, elaborada pelo idealismo alemão, foi feita pelo fenomenólogo português Joaquim de Carvalho, com as pistas fornecidas por Edmund Husserl. O fundamental de sua obra foi resumido no livro História da Filosofia e Tradiçôes Culturais. A interpretação hegeliana da história da filosofia indicava a relatividade de todas as filosofias, problema que ele resolveu, identificando História e Razão. Edmund Husserl notou que essa identificação culminava num
} 
5. Além desses elementos que permeavam a cultura filosófica, no início do século XX, o filósofo espanhol José Ortega y Gasset concluiu que o grande problema a ser enfrentado pela Filosofia do seu tempo era uma nova forma de opor a subjetividade moderna à perspectiva objetivista dos gregos. Fazê-lo significava propor uma nova subjetividade indo além do que fizera o criticismo de Emmanuel Kant, tarefa que, contudo, não podia negligenciar a novidade trazida pelo subjetivismo moderno. Adicionalmente, o princípio metafísico proposto devia amparar as ontologias regionais associadas por Edmund Husserl às ciências de fatos singulares como a História ou de experiências gerais como a Física. $\mathrm{O}$ princípio precisava ainda enfrentar a preocupante crise de civilização sentida de vários modos pelos filósofos de entâo, com forte impacto sociológico na vida do ocidente. A crise trazia mudanças profundas no modo de pensar e desmontava crenças antigas em verdades imutáveis e na natureza estável do mundo, herdadas da concepção metafísica aristotélica, a qual continha determinaçóes de todo ser e estava presente nas formas e maneiras particulares dos entes.

6. Como a crise de civilização atingia costumes sociais e a organização política dos povos, o novo princípio precisava, além de considerar os problemas ontognoseológicos, solucionar as dificuldades éticas e políticas da sociedade europeia. Eram esses os desafios que Ortega y Gasset considerava devessem ser enfrentados pela filosofia do seu tempo. Não eram poucos nem simples os problemas à espera de solução.

7. Essas questóes começaram a ser abordadas por Ortega y Gasset em seus primeiros trabalhos. Neles, a vida é proposta como realidade fundamental. Em Meditaciones del Quijote (1914) e nos oito livros de El espectador (19161934), o filósofo apresenta o princípio metafísico que deveria orientar a meditação filosófica de seu tempo, mas é em Qué es filosofía? (1929), Unas lecciones de metafísica (1933) e em La rebelión de las masas (1930), assim como no ensaio Pidiendo un Goethe desde dentro (1932), que ele sistematiza suas meditaçóes e dá densidade teórica à relação entre o eu e o mundo que estão na base da vida. É nos três livros que ele apresenta sua concepção metafísica de forma rigorosa, inserida na tradição filosófica do ocidente e com a pretensão de apresentar uma nova teoria filosófica. Com ela, enfrentava os desafios de

historicismo absoluto, o qual pedia uma justificativa rigorosa da reflexão filosófica e uma separação entre os conceitos, como já mencionamos em outra oportunidade. Conforme frisamos Joaquim de Carvalho fez precisa crítica das posições fenomenológicas sobre a história da filosofia. Escrevemos (2001): "Joaquim de Carvalho explicou que Husserl tinha razão ao separar espírito e história, mesmo reconhecendo que esta última é o espaço do espírito e que aquele possui história” (p. 61). 
seu tempo, tanto os problemas trazidos pela compreensão parcial e histórica da verdade quanto a crise de civilizaçáo.

8. Neste artigo, vamos mostrar como o filósofo caracteriza o fundamento de sua teoria geral da realidade. A vida é o modo de ser fundamental, pois é a base sobre a qual as verdades do homem se estabelecem. Ao propor tal princípio, o filósofo critica os rumos da Metafísica tradicional, voltada para elementos estruturantes do real localizados no pensamento puro. Ele prefere tratar a vida como travamento do real, vida experimentada na primeira pessoa, ou melhor, na relação insuperável entre o eu e a circunstância. Partiremos da qualificação de vida feita pelo filósofo, nos seus escritos iniciais. Neles, Ortega y Gasset já descreve a relação entre o eu e a circunstância; em seguida, apresentaremos a inserção de suas análises na história da metafísica, assunto dos trabalhos do final da vida, quando suas ideias ganham dimensão filosófica.

\section{A CARACTERIZAÇÁo DA VIDA COMO FUNDAMENTO}

9. No ensaio Julian Marias y la metafísica orteguiana, Helio Carpintero observa que a filosofia orteguiana está inteiramente impregnada pelo desafio metafísico de compreender a realidade. Ele destaca, dos comentários de Marías, a avaliação do raciovitalismo como "[...] um ponto de inflexão na história da metafísica” (p. 211). Trata-se, portanto, de uma mudança ou desvio, mas qual? O fundamental da mudança, sustenta ainda Carpintero, está consolidado nas obras Que és filosofía? e Unas lecciones de metafísica, pois, nelas, a vida aparece como a realidade fundamental que os filósofos buscam desde a antiga Grécia. A esses textos é preciso acrescentar alguns outros, conforme indicaremos. Igualmente, sabemos que a utilização da vida como eixo articulador das teses filosóficas orteguianas, tratadas como inflexão por Carpintero, aparece em trabalhos anteriores aos livros mencionados. Praticamente toda obra orteguiana, desde as Meditaciones del Quijote (1914), se dedica a caracterizar a vida como o problema fundamental de nosso tempo. Essa afirmação pode ser comprovada no capítulo VII de El tema de nuestro tiempo (1923). Ali, afirma o filósofo que a cultura humana comprometida com a busca da verdade estava diante de um novo desafio (1994a, v. 3, p. 179): “[...] consagrar a vida, que até agora era só um fato nulo e como que um erro do cosmo, [...] um princípio e um direito". O filósofo esclarece, na sequência do capítulo, que a vida esteve a serviço da religião, da ciência, da moral, da economia, da arte etc., apenas não foi tomada em si e fundamento de todo o resto. Tratar a vida como realidade 
essencial foi próprio de um tempo que nela reconhece o sentido principal da realidade buscado pela Filosofia. Assim ocorreu porque, conforme observa Roger Garaudy (1966, p. 18), experimenta-se o sucesso “[...] de uma concepção de ciência, a do positivismo, que a priva de sua significação humana". Por conseguinte, o conceito de metafísica como problema do conhecimento, pensado pelos modernos como tentativa de chegar a uma verdade irrecusável, reaparece na procura do sentido necessário e anterior à prática da ciência. A questáo pede o exame da subjetividade e do modo como ela se relaciona com o entorno. O que é a vida? Como caracterizá-la? Garaudy sugere que o problema de Ortega y Gasset era o de sua geração.

10. Tratar a vida como problema central a ser investigado é desafio que vinha da herança kantiana e estava sendo enfrentado pela fenomenologia. O tema teve uma abordagem própria nas Meditaciones del Quijote. Nessa obra, Ortega y Gasset define viver como resultado da relação entre o eu a circunstância. A inserção do eu no mundo faz da vida um compromisso que se deve estudar com determinação. Daí a caracterização da vida como o grande problema a ser desvendado. Dito de outro modo, viver é realizar um programa, um destino, desenvolver um projeto vital num mundo que se encontra aí. Esse eixo nuclear da ontologia orteguiana já aparece na introdução das Meditaciones del Quijote, lembra Gilberto Kujawski, e se expressa na frase que passou a caracterizar o raciovitalismo a partir de então (1994, p. 39): "Eu sou eu e minha circunstância, se não salvo a ela também não salvo a mim". Assim, a característica principal da ontologia raciovitalista é conceber a vida como a tarefa de vencer a circunstância no quanto ela impede a realização do projeto vital. A ação humana guarda uma fidelidade ao núcleo interior do sujeito que o filósofo formula como obrigação ética. Quando escolhe, o sujeito está inevitavelmente vinculado à circunstância ou, como enfatizamos (2010, p. 113), “[...] ao escolher vamos tecendo nossa vida, alterando a circunstância”. Circunstância, para o filósofo, "[...] é tudo o que rodeia o eu: a realidade cósmica, a corporalidade, a vida psíquica, a cultura em que se vive, nela incluído as experiências acumuladas no tempo" (CARVALHO, 2009, p. 332). A tarefa vital é, assinala Ortega y Gasset, em Ideas sobre Pio Baroja (1998b, v 2, p. 75), “[...] querer ser, antes de tudo, a verdade do que somos". Em síntese, a primeira característica da vida, para Ortega y Gasset, parece ser esta: vida é tarefa, compromisso inadiável e irrecusável que temos conosco de vencer a circunstância, no que ela interdita meu projeto vital. 
11. A realização do projeto vital depende do tipo de vitalidade que se tem e que varia entre as pessoas, povos e épocas. Trata-se de imposição biológica que é diferente nas pessoas e sociedades, segundo esclarece o pensador, no ensaio El Quijote en la escuela. Ali, afirma (1998a, v. 2, p. 291): “[...] antes que fale a ética, tem direito de falar a pura biologia. Sem sair dela, desde o ponto de vista estritamente vital, nos aparece um valor biológico positivo, como vitalmente bom, e outro, como valor biológico negativo, como vitalmente mal”. Eis a segunda característica da abordagem orteguiana à vida, a realização do projeto vital é uma escolha que envolve mais coisas que uma decisão racional. Ela possui um aspecto ético, mas o ímpeto com que a escolha é realizada depende do impulso vital que é biológico. É a vitalidade o que faz um povo ou um indivíduo ser mais vibrante e emotivo, mais rápido ou lento na conduçáo do tempo vital. A vida possui um tônus vital e isso a caracteriza.

12. A condução do projeto vital não se realiza do mesmo modo em todos os períodos da história. É importante identificar os apelos de cada época para apreender o modo como a vida é conduzida. O entendimento de que o projeto vital é singularíssimo, porque diz respeito a cada indivíduo, pede mais que a observação do tônus vital e os aspectos da personalidade. A compreensão exige que se considere também o tempo histórico, porque ele impacta a vida singular, conforme seja um momento de maior tranquilidade ou de crise, segundo seja um período mais preocupado com os prazeres do que em evitar as dores, ou mais ocupado em evitar dores que obter prazer. Não só a existência singular é temporal, o horizonte social também é, e afeta da vida pessoal. No ensaio Elogio del murciélago, escreve Ortega y Gasset (1998d, v. 2, p. 321): "Algumas vezes me ocorreu pensar que há duas classes de épocas históricas: em umas, os homens se preocupam mais em buscar os prazeres que evitar as dores; em outras, acontece o inverso". De acordo com a orientação da época, a vida ganha balizamentos distintos segundo vise mais ao prazer ou fugir das dores. Dessa maneira, a realização do projeto vital obriga o homem a voltar-se sobre si porque, como destacamos (1996, p. 84), “[...] a pergunta sobre si é o que há de mais fundamental para Ortega y Gasset”. Eis aí a terceira característica da meditação orteguiana: a vida só se esclarece quando se considera o momento histórico em que é vivida, já que é "[...] o homem mergulhado na história que procura intensamente compreender-se” (p. 84). A vida singular é temporal e é vivida numa sociedade que também é histórica e cujas características afetam o drama vital. 
13. Ao pensar a vida como resultado de escolhas, Ortega y Gasset observa que as opçóes preferidas pelo sujeito formam uma espécie de trilha na memória pessoal. Tal trilha revela preferências e dá forma ao passado do sujeito. Todos podem conjecturar a respeito dos outros caminhos que seriam percorridos se, ao invés das escolhas feitas, tivessem outras sido feito. A vida seria distinta do que é, mas vida mesmo é o que é. As escolhas podem levar a uma vida mais ou menos densa, mais ou menos charmosa ou mais ou menos profunda. Eis o que assevera o filósofo acerca das inúmeras alternativas que compóem as vidas não vividas que tínhamos à disposição, no ensaio Intimidades (1998c, v. 2, p. 637):

[...] minhas memórias contaram, junto à minha vida efetiva, o que pude viver, vidas perdidas antes de nascer, pobres existências que para sempre caíram sem vida, sem ser cumpridas, espectros errantes que são nosso múltiplo ser fracassado. Não se trata de abstratas possibilidades, senão que cada ser humano leva em torno ao núcleo de sua existência efetiva um elenco concreto, individualíssimo de outras possíveis vidas, suas e só suas.

Esta é a quarta característica da definição de vida: a existência real é um núcleo em torno do qual circundam outras vidas possiveis que teriam sido vividas se, ao invés de um curso, tivesse o sujeito feito outro. Se, ao contrário de me casar com alguém, tivesse escolhido outro ou outrta parceira, se, ao invés de um trabalho, a opção fosse outra, minha vida seria outra. A vida do homem é um fenômeno particularíssimo que brota de escolhas e caracterizaçóes de possibilidades que acompanham o núcleo central não tendo sido, embora pudessem ser. A vida é um destino construído com escolhas entre muitas outras possíveis.

14. Vida é ação, é resultado de escolhas que se sucedem continuamente. Como fazê-las? A questão considera a agilidade e vigor com que se age. Construímos uma trilha, com qual ritmo o fazemos? O filósofo propóe uma espécie de tocada segura, contínua, mas sem afobamento, num dos discursos parlamentares no advento da República. Em 4 de setembro de 1931, comentou sobre a renovação da vida na Espanha (1994e, p. 384): "Façamos, como toda grande reforma [...] - que vamos intentar com o tempo justo, sem acelerarmos, porém sem retardarmos, seguindo, pois, a norma que Goethe recomendava para toda nossa vida: avançar sem pressa e sem pausa, como a estrela”. Estamos diante da quinta característica da análise orteguiana: a vida das pessoas e dos povos tem um ritmo que lhe é próprio. 
15. Aproximando a característica anterior da primeira, conclui-se que a vida tem um ritmo ótimo. A realização da tarefa vital coloca em evidência o limite temporal, pois a vida é um processo com duração e é enquanto se vive que o projeto deve ser realizado. $\mathrm{O}$ resultado das combinaçôes é que o tempo para realizar o projeto vital é curto, e isso acirra a responsabilidade das escolhas. Não há tempo a perder, porque morrer ou deixar de ser significa tornar-se indiferente a tudo. Assim, intimamente, o tempo vital é sentido como pressa, explica o filósofo, no anexo de Idea del teatro (1997a, v. 7, p. 500): "Vida humana é, pois, de pronto, certa duração normal da pessoa, certo tempo que lhe é concedido e que é sempre escasso. À nossa vida lhe falta sempre tempo, por isso é essencialmente pressa”. Chega-se, então, à sexta característica: embora a vida tenha ritmo, enquanto percepção intima, ela é pressa, a vida é pressa de realizar o projeto vital. O projeto, já foi frisado, não é um plano intelectual, mas o autêntico ser reconhecido por cada eu como sua trilha ou destino.

\section{A VIDA COMO PROBLEMA METAFísICo}

16. No livro Que és filosofía? Ortega y Gasset reafirma que a vida é realidade radical que nasce da relação entre o eu e a circunstância. Tema central de todos os seus estudos, desde Meditaciones del Quijote, a novidade expressa no livro, conforme sintetiza Amoedo (2002, p. 257), é "[...] a necessidade (filosófica) de expor a sua tese fundamental dando-lhe agora uma formulação tão rigorosa que ela pudesse manifestar-se a todos como uma inovação radical da filosofia". A inovação, no que se refere à metafísica, é tratar a vida como realidade fundamental, isto é, como elemento estruturador do real buscado por todos os filósofos. Sobre a vida, a Filosofia deve centrar a atenção e descrever as características principais. Afirma o filósofo (1997b, v. 7, p. 405): "Viver é o que ninguém pode fazer por mim - a vida é intransferível, náo é um conceito abstrato, é meu ser individualíssimo”. E o que é este ser? Como ele se tornou um problema filosófico?

17. Ele comenta o que significa tratar a vida pessoal como realidade particularíssima, no livro En torno a Galileo, publicado em 1933, mesmo ano de Unas lecciones de metafísica. Ali, o filósofo esclarece o caráter pessoalíssimo do viver. Ninguém pode viver pelo outro, em outras palavras, ninguém responderá aos desafios que eu tenho que resolver. É nesse sentido que a vida é inalienável e singularíssima, declara o filósofo (1994c, v. 12, p. 23): 
O homem, cada homem, tem que decidir a cada instante o que vai fazer, o que vai ser no momento seguinte. Essa decisão é intransferível, ninguém pode substituir-me na faina de me decidir, de decidir minha vida.

18. Voltemos ao eixo central de Que és filosofía? Para o filósofo, a melhor forma de tratar os assuntos filosóficos é fazendo círculos concêntricos em torno do problema. Com o método, é possível voltar várias vezes aos mesmos assuntos e, a cada nova volta, aprofundar a investigação. O que uma primeira aproximação da metafísica mostra? A impossibilidade de a disciplina chegar às verdades universais que almeja alcançar. $\mathrm{O}$ resultado do filosofar é uma verdade incompleta, construída e melhorada pelas geraçóes. Ao caracterizar o tempo que antecede suas análises, ele o considera um momento ruim da Filosofia; nele, a Física alcançou grandes êxitos e a ciência fora tida como o único saber válido. Ortega y Gasset observa que a Filosofia não é uma ciência, ela é mais, é um saber que trata a realidade de forma radical. Uma (1997b, v. 7, p. 335) "segunda volta" mostra o pensar filosófico como "[...] imprescindível procura de conhecer tudo que há". Cada ciência tem o seu objeto, o da Filosofia é o que não pode ser dado. A Filosofia é um saber radical, sem pressupostos. Embora ela náo trate do que é imediato ou útil, a Filosofia é necessária, pois fundamenta outros conhecimentos. $\mathrm{Na}$ "terceira volta", o filósofo examina os erros das antigas filosofias. Ele considera que o desafio de seu tempo era superar a verdade idealista e a reduçáo que ela realiza no conhecimento da realidade. É preciso fazer com o idealismo o que ele fez quando apontou os erros do realismo grego. O idealismo é uma teimosa e tenaz marcha contra o curso da vida, avalia Ortega y Gasset. A filosofia idealista desvitalizou a vida, sendo importante superar os erros que isso significou. Assim, a superação do realismo grego e do idealismo alemão pede outra Filosofia, que afirme a contribuição do idealismo sem ficar no seu erro, isto é: uma nova filosofia da vida. É, portanto, como forma de superar o realismo e o idealismo que o autor tematiza a vida como problema fundamental. Chega-se à "quarta volta", representada pelo desafio de pensar a subjetividade idealista na circunstância, já que a subjetividade não se afasta do entorno. Ortega y Gasset propóe a vida como o problema a ser investigado pelos filósofos contemporâneos. Viver é condição fundamental e consiste em coexistir com o entorno. O ser estático das filosofias antigas será substituído por um ser atuante aberto a mudanças. "O filósofo antigo busca o ser das coisas e inventa conceitos que interpretam seu modo de ser" (1997b, p. 393), o contemporâneo precisa entender a vida. Viver é o que fazemos e o que se passa conosco. Eis a característica básica 
descoberta com os giros envolta do problema vida: viver é uma revelação, “[...] é encontrar-me no mundo" (p. 424). O assunto tem significado filosófico, quando Ortega y Gasset trata a vida como o ser fundamental.

19. Antes de entrar na caracterização da vida como problema filosófico, vejamos o que é propriamente uma abordagem filosófica, para nosso filósofo. No livro La idea de principio en Leibniz y la evolución de la teoría deductiva, ele explica o conhecimento filosófico e assevera que Leibniz é, por excelência, um filósofo de princípios. Para Ortega y Gasset, Leibniz realiza com maestria o que todo filósofo busca construir: princípios que forneçam certezas para pensar o real. O conhecimento filosófico é atividade que se faz, formulando princípios fundamentais. Ortega y Gasset afirma (1994d, v. 8, p. 63): "Em filosofia isto se leva a extremos [...], se exige dos princípios que sejam últimos, isto é, em sentido radical, princípios”. Leibniz, enfatiza Ortega y Gasset, é o filósofo mais completo da modernidade e, pela extensão de seus interesses e estudos, deixou contribuição comparável à de Aristóteles para a antiguidade. Ortega y Gasset pensa que os princípios construídos num certo tempo traduzem uma concepção de mundo e que ela é a base das crenças que representam a forma de pensar daquele tempo. Filosofia é, assim, construção de princípios fundamentais, conforme comenta Julián Marías, no espírito do mestre, em sua História da Filosofia (2004, p. 507): "A filosofia é, portanto, a verdade radical, que não suponha outras instâncias ou verdades, tem, além disso, de ser a instância superior para todas as verdades particulares”. Passemos, na sequência, à caracterização da vida no contexto da metafísica.

20. Na filosófica caracterização orteguiana de vida, comecemos com a assertiva negativa proposta em Que és filosofía?: a vida é um ser que não possui determinação fixa. A metafísica, tanto na perspectiva realista dos gregos quanto na idealista dos modernos, quando se refere à realidade fundamental, atribuilhe estabilidade. Para os gregos, realidade fundamental foi que as coisas existem verdadeiramente e formam uma unidade. E o que são mesmo as coisas? Aquelas, cujo ser independe do meu pensamento. A perspectiva moderna ou idealista entende que o fundamental é o que se impóe, mas isso que se impóe depende do pensamento reconhecer-lhe a existência. Nesse sentido, chega-se a um impasse: o que é fundamento depende da consciência para assegurá-lo. Entretanto, sem a consciência, o mundo perde realidade, a realidade passa a depender do sujeito ou, como sintetiza Mindán (2009, p. 202), "[...] a consciência não agrega realidade a um novo objeto que está aí, senão que modifica essencialmente a tese”. O idealismo começou sustentando que, para haver coisas no mundo, é preciso um 
eu que o pense. No entanto, foi além e fez depender o ser das coisas do eu - e isso é um exagero, avalia Ortega y Gasset. Nosso filósofo conclui que, se não houvesse mundo, não haveria consciência, pois sem mundo não há eu. É assim que postula ser a vida a realidade que a Filosofia busca, durante toda história, segundo lembra Mindán: "A realidade radical está na dualidade constitutiva do mundo e o homem e podemos comprovar que isto é precisamente a vida humana" (2009, p. 204). Na perspectiva de Ortega y Gasset, a vida, com toda sua instabilidade, é a realidade fundamental buscada na história da metafísica. Atribui-lhe uma dignidade que ainda não lhe fora reconhecida por nenhum pensador, porquanto está nela a razáo maior do filosofar. Estamos diante, destaca o filósofo, no livro Que és Filosofia?, "[...] de uma nova ideia de ser, de uma nova ontologia, de uma nova filosofia e, na medida em que esta influi na vida, de toda uma nova vida - vida nova" (1997b, p. 408). Eis aí o sentido filosófico de viver: ver o mundo, pensá-lo, tocá-lo, apalpá-lo, senti-lo, saboreá-lo, amá-lo ou não. É a soma de tudo isso que se chama viver. Vida é fenômeno que contempla a relação do sujeito com o mundo de um modo que náo fora percebido antes, nem pelo realismo, nem pelo idealismo. Eis a caracterização básica e fundamental proposta no princípio: ser é viver e contempla relação especial com o mundo.

21. A descrição da vida como vitalidade, como fora feito em El Quijote en la escuela, ganha tratamento mais elaborado na lição X, de Que és filosofía? $\mathrm{O}$ aprofundamento filosófico e a identificação entre vida e ser fundamental aperfeiçoarão a forma como o filósofo avalia o significado do corpo e do seu funcionamento. Vida não é resultado de um processo biológico, assunto que pode ser tratado pela ciência biológica. Ele explica (1997b, v. 2, p. 413): "Meu corpo mesmo náo é mais que um detalhe do mundo que se encontra em mim, detalhe que, por muitos motivos, é de excepcional importância, porém que não deixa de ser apenas um ingrediente entre inumeráveis que há no mundo ante mim". Os movimentos psíquicos, os sentimentos e emoçôes, por mais intensos e consoladores que sejam também não traduzem a realidade fundamental e, como o corpo, integram a circunstância. Corpo e vida são objetos dos quais a ciência pode dar conta, como também afirma Karl Jaspers, na sua Iniciação Filosófica (1987, p. 61): "O homem, enquanto existência no mundo, é objeto suscetível de conhecimento”. E, como fizera Jaspers, Ortega y Gasset distinguirá vida dos processos estudados pela ciência, mas não a identificará com liberdade, como fez o filósofo alemão, ao propor, no espírito do kantismo, que "[...] ser homem é fazer-se homem" (1987, p. 67). Ortega y Gasset tratará a vida como um nível profundo de consciência expresso em Que és filosofía? do seguinte modo (1997b, v. 2, p. 414): “[...] viver é o que 
fazemos e o que nos passa”. A definição assim explicita a consciência de viver: "[...] viver é essa realidade estranha, única, que tem o princípio de existir para si mesmo. Todo viver é viver-se, sentir-se viver, saber-se existindo - donde saber não implica conhecimento intelectual nem sabedoria especial nenhuma" (1997b, p. 414). Chega-se, assim, a esta outra característica filosófica da vida: viver é consciência especial do que fazer, de como se ocupar da nossa circunstância ou, nas palavras de Julián Marías, seu intérprete mais conhecido, de modo mais sintético (2004, p. 506): “[...] vida é algo que temos que fazer”.

22. Ao se aproximar da herança fenomenológica, Ortega y Gasset considera a vida como um que fazer que necessita do eu e do mundo como instâncias inseparáveis. Não se pode mais tratar de um sem considerar o outro. O homem relaciona-se com o que o circunscreve e o afeta, quer sejam coisas materiais, quer não. Essas coisas tanto constituem oportunidade de realização de projetos como são limites que impedem sua realização. O filósofo apresenta, em Que és filosofía?, um conceito de mundo definido como conjunto de coisas. E acrescenta (1997b, v. 2, p. 416):

[...] o importante não é que as coisas sejam ou não corpos, senão que elas nos afetam, nos interessam, nos acariciam, nos ameaçam e nos atormentam. Originariamente isto que chamamos corpo não é senão algo que nos resiste e nos estorva, ou nos sustenta e leva [...]. Mundo, em sensu stricto, é o que nos afeta.

Embora Ortega y Gasset garanta que o seu entendimento do mundo se afasta do de Martin Heidegger, a aproximação fenomenológica é, nesse caso, evidente em relaçáo ao que Karl Jaspers denomina realidade, a saber (1987, p. 69): “[...] o que nos é presente na prática e que, no convívio com as coisas, com os seres viventes e com os homens, nos oferece resistência ou se materializa”. Assim, temos uma compreensão de mundo ou realidade como conjunto de coisas que nos afeta e do qual náo temos como nos separar. Tal compreensão revela o caráter dramático da vida, pois não há como se separar de um mundo que não se escolheu para viver. Podemos fazer ou não coisas, porém, não podemos abandonar o mundo que nos é dado. É o que salienta Ortega y Gasset, na obra examinada (1997b, v. 2, p. 417):

[...] isto dá à nossa vida um gosto terrivelmente dramático. Viver não é entrar em um lugar previamente escolhido por gosto, como se escolhe um teatro depois de jantar - senão que é encontrar-se de pronto e sem saber como caído, submerso, projetado em um mundo. 
O conceito de drama existencial apresentado por Ortega y Gasset lembra a derrelição de Martin Heidegger, para quem o homem tem que viver num mundo que não escolheu. Ele se acha jogado na situação, o homem entra no mundo sem razão prévia e de forma contingente. Eis aí a terceira característica da vida: vida é drama, é estar num mundo em que não se escolheu viver e do qual não há como escapar. É nele que se vive o projeto vital.

23. A definição da vida como um que fazer da circunstância considera viver atividade contínua. A vida é tarefa permanente. Fazê-la está nas mãos de cada sujeito, explica o filósofo: "[...] fomos jogados em nossa vida e isto em que fomos lançados temos de fazer por nossa conta, por assim dizer, fabricá-lo. Ou dito de outro modo: nossa vida é nosso ser" (1997b, p. 418). Ora, se viver é o que fazemos neste espaço em que fomos arremetidos, temos os olhos voltados para o futuro, estamos orientados para lá muito mais que condicionados pelo passado. A abertura ao futuro, concebido como transcendência no tempo, é compreensão que Ortega y Gasset partilha com os filósofos existencialistas. Esse entendimento se expressa na ideia de projeto: o homem abre-se ao futuro, orienta-se em direção ao que ainda não é, pois o homem não está pronto no ponto em que está. Pelo projeto vital, a vida adquire sentido na circunstância. Assevera o pensador: “[...] viver é constantemente decidir o que vamos ser. Não percebem o fabuloso paradoxo que isto encerra? Um ser que consiste no que é e no que vai ser, portanto no que ainda não é" (1997b, p. 419). Chegamos, por conseguinte, a esta outra característica da vida: a vida entendida como projeto é fundamentalmente o que ainda não é, a vida é futurição, o que equivale a "[...] viver avançando em nosso futuro" (p. 435). E aqui novo ponto de aproximação com Martin Heidegger, como já assinalamos (2002, p. 73): “[...] viver é pre-ocupar-se, é ocupar com o que havermos de fazer, sorge".

24. No ensaio Pidiendo un Goethe desde dentro, Ortega y Gasset completa a caracterização da temporalidade humana. Se vida é essencialmente futurição, como indicamos no parágrafo anterior, o passado de cada um e da sociedade não é desprezível. É a ênfase no passado como saber acumulado que fornece os elementos para enfrentar as novas crises pelas quais, às vezes, passa a sociedade humana. E o século passado viu surgir uma crise social profunda, a qual Ortega y Gasset examinou na sua obra mais conhecida, La rebelión de las masas $(1930)^{3}$. Esse é o tempo em que as massas desejam ser sujeito da

\footnotetext{
${ }^{3}$ A crise do século passado tem origem, para Ortega y Gasset, na sociedade de massas. As massas desejaram ser, no século XX, o que não foram em outras épocas, as protagonistas principais da história. O tempo das massas é o tempo da hiperdemocracia e da desvinculação entre esforço e vida nobre. $\mathrm{O}$ assunto foi examinado em $O$ século XX em El Espectador de Ortega y Gasset: a crise como desvio moral (2010).
} 
história e onde se perdem as referências do passado. Quando, no espaço social, os desafios não encontram referências onde se apegar e resolver os problemas, a vida mostra a sua face de risco, de perigo e naufrágio. $O$ assunto será também mencionado em Ensimesmamiento y alteración (1939), onde a noção de perigo se explicita na política. No ensaio sobre Goethe, o assunto tem tratamento metafísico e se expressa, segundo síntese de Gilberto Kujawski, nesta tese (1986, p. 3): “[...] o perigo é coextensivo à vida mesma. De forma radical: o perigo como substância da vida, esta consiste substancialmente em perigo". Chega-se, assim, a nova característica da vida, pelo risco que lhe é inerente. Vida é risco. Para enfrentar o risco, é preciso se agarrar à cultura, à experiência que ela acumulou. É nela que o homem vai encontrar os elementos importantes para se defrontar com a verdade da sua vida. Há, na compreensão orteguiana, muita semelhança com o que refere Karl Jaspers sobre o sentido do passado na existência (1987, p. 89): "[...] a experiência do presente compreende-se melhor refletida no espelho da história”. No entanto, a própria vida se incumbe de estabelecer o sentido do risco para superar, como afirma no ensaio (v. 4, 1994b, p. 397): “[...] o grande inconveniente de que o

Ali, afirmamos que "[...] a característica fundamental da crise do século XX era uma atitude comum que, para Ortega y Gasset, marcava a relação entre a massa e a minoria da sociedade. É bom lembrar que para o filósofo esta é uma divisão comum a todas as sociedades. O que ele observa é que no século $\mathrm{XX}$, as minorias mais bem educadas nos diversos campos culturais náo assumiam a tarefa de dirigir a sociedade, não respondiam aos novos desafios que a vida apresentava, mas cultivavam um saber muito especializado e ignoravam quase todos os outros assuntos. Estas minorias náo formavam uma classe social ou grupo, mas se definiam pelas funçóes que possuem. A ignorância destas várias elites representa uma nova forma de barbárie que é complementada pela inocência infantil com que elas julgam a vida e a acham tudo muito fácil. Esta interpretação que o filósofo elabora nos ensaios de El espectador será desenvolvida em La rebelión de las masas, livro onde explica que o homem do seu tempo deixou de se empenhar com afinco na edificação de uma vida melhor. Este homem aceita a mesmice e se conforma com o modo de vida mais comum. Este doutor ignorante e infantil é o homem massa. O homem massa é o medíocre que não se arrisca em grandes obras e não se entrega a uma causa. $\mathrm{O}$ homem massa nấo se empenha na conduçáo da vida pessoal entendida como projeto vital e rigorosamente singular. Uma vida humana plena implica no desenvolvimento de uma vocação singular. Ela possui um caráter próprio, é povoada por tensóes e dramas oriundos do que fazer vital” (p. 15). Portanto, com a ideia de massa, Ortega y Gasset anunciava a emergência de uma hiperdemocracia, constituída paradoxalmente por um sujeito individualista e infantil: o homem massa, preocupado em assegurar o gozo imediato, no mais das vezes irresponsável. Ele antecipou muito bem o quadro descrito por Lipovetsky e Serroy, em A cultura mundo (2011), embora não partilhasse das referências filosóficas da Escola de Frankfurt, as quais marcam as análises dos dois autores do livro mencionado. Vivemos num tempo, afirmam os dois franceses, "[...] de transformaçóes que permitem falar de um novo regime de cultura, o da hipermodernidade, em que os sistemas e valores tradicionais que perduraram no período anterior não são mais estruturantes, em que já não são verdadeiramente operantes senão os próprios princípios da modernidade. Além da revitalização das identidades coletivas herdadas do passado, é a hipermodernizaçáo do mundo que avança, remodelado que ele está pelas lógicas do individualismo e do consumismo" (p. 13). 
homem acredite estar seguro e perca a emoção do naufrágio é que a cultura se torne obra parasitária”. A vida, portanto, é risco, perigo, mas há, na cultura, os elementos com os quais o homem pode reconstruir suas crenças. E então, quando não há verdades prontas a que se apegar, o momento em que "[...] os braços voltam a se agitar salvadoramente" (1987, p. 397). A salvação da vida ocidental está na consciência dos riscos do naufrágio que chega com o tempo das massas e da hiperdemocracia. Este é o risco que a vida corre em nosso tempo, avaliava Ortega y Gasset, como indicamos no livro Introdução à Filosofia da Razão Vital (2002, p. 76): "O homem massa é insensível ao legado das antigas geraçóes, incapaz de novos esforços, cego para o fato de que a vida autêntica é aquela que se sabe desafio". Uma rápida descrição do que está ocorrendo ainda em nossos dias, mais de cinquenta anos depois da morte do filósofo - individualismo exacerbado, democracia de massas, desconfiança dos valores, hedonismo consumista e irresponsável - é suficiente para perceber que os riscos identificados por Ortega y Gasset permanecem, no que ele denominou nova barbárie.

25. O livro Unas lecciones de metafísica foi elaborado, segundo testemunho de Julián Marías, a partir de um curso ministrado em 1932/1933, na Universidade de Madrid, cujo título era Princípios de metafísica segundo a razão vital. O curso revela uma doutrina original e com princípios claros, os quais permitem adaptá-la às diferentes situações, inová-la e modificá-la. Nas Obras Completas, os manuscritos do curso foram completados com anexos deixados por Ortega y Gasset. Um se refere especificamente à lição VI e o outro tem caráter geral. Os anexos tinham merecido uma edição separada na Revista do Ocidente, em 1965, mas aparecem publicados no livro apenas nas Obras Completas. Sobre o curso que deu origem ao livro, escreveu Marías (1991, p. 209):

Nestas liçóes aparece in statu nascendi a metafísica de Ortega, a que desde então chamava metafísica segundo a razão vital [...]. Tem-se presente quanto caminho percorreu a metafísica, que zonas da realidade explorou, até onde levou a visão desveladora e conceitual da realidade, pode-se ter a impressão adequada de sua vitalidade como atitude.

26. A reflexão metafísica tem por propósito saber o que são as coisas de modo radical. É da reflexão metafísica que surge a descrição da vida como processo especial de consciência, que se expressa em três características assim apresentadas pelo filósofo (1997c, v. 12, p. 47): “1. A vida se inteira de si mesma, 
2. a vida se faz a si mesma e 3. a vida se decide a si mesma". Ele também trata a vida como consciência, do seguinte modo: "[...] todo viver é viver-se, sentirse viver, saber-se existindo; donde saber não implica conhecimento intelectual nem sabedoria especial nenhuma, senão que é essa surpreendente presença que sua vida tem para cada qual, sem esse saber-se, sem esse dar-se conta, a dor de dentes não me doeria" (p. 33). O conhecimento metafísico fornece não a posse da coisa, mas seu ser. Fazer e pensar são regiốes diferentes da vida de cada pessoa. O que o pensar metafísico revela? $\mathrm{Na}$ compreensão orteguiana, que o mundo das coisas é um grande vazio de ser. A metafísica procura, justamente, clarear o que há para além do que aparece, ensina o filósofo, no texto transcrito a seguir: "[...] na pergunta: que é a Terra? (o interlocutor) aspira chegar a esse vazio, a encontrar por traz desse náo ser da Terra seu caráter positivo, a substituir a impressão de insegurança que experimentamos por um estado de segurança”" (1997c, p. 86). Nesse sentido, a vida é circunstancial: "[...] viver é encontrar-me, queira ou não, entregue a uma circunstância” (p. 47). Dela é preciso se ocupar, o que significa que o sujeito executa um plano único. A metafísica lhe fornece tal plano. Esse plano é particular, como já sublinhamos, pois a vida de cada sujeito é singular. Daí se constata outra característica fundamental da vida: o plano que é arquitetado pelo sujeito é elaborado na mais absoluta solidáo, explica Ortega y Gasset: "[...] de verdade fazemos metafísica quando fabricamos nossas convicçóes radicais, o que temos que fazer cada qual por si, em radical solidão" (p. 101). Pode-se fazer a seguinte síntese, com as características enumeradas pelo filósofo: a vida é um saber-se vivendo em solidão.

27. As duas grandes perspectivas desenvolvidas na tradição filosófica são, para Ortega y Gasset, a realista e a idealista. Trata-se de reconhecimento da validade da leitura kantiana da tradiçáo filosófica. As duas perspectivas representam, em síntese, o esforço humano para vencer a insegurança da perda de certezas que ocorre com as mudanças na compreensão das coisas. A tese idealista é mais completa que a anterior, reúne o trabalho de muitos filósofos modernos, todavia, tem como problema que a realidade náo representada na consciência parece seguir independente dela. Além disso, se o idealismo estivesse certo, só existiria pensamento - o que parece absurdo, avalia Ortega y Gasset, no texto que se segue: "[...] se a realidade radical é o pensamento, quer dizer que, propriamente falando, não há mais que pensamento. Adeus coisas, mundo, amigos. Tudo isto não é, em verdade, mais que um enxame de ideias. Sou um cego que sonhava que via" (1997c, p. 122). O homem precisa estar ante as coisas para que elas existam, mas o real não é só pensamento, porque o que existe é mais que pensamento. Assim também, eu não sou minha 
vida, pois ela é mais que o eu. As consideraçóes de Ortega y Gasset tratam a vida como resultado de duas instâncias, uma imanente e outra transcendente, como se vê nesta passagem: "[...] as coisas não são eu, nem eu sou as coisas, porém ambos somos imanentes a esta coexistência absoluta que é a vida" (p. 127). Eis a caracterização sugerida no texto: a vida é coexistência absoluta do eu e das coisas, implica um que fazer dentro de determinada circunstância.

\section{Consideraçóes finais}

28. A apresentação da vida como assunto fundamental da Filosofia é o tema central da meditação orteguiana e foi o objeto deste trabalho. Ao tratar do entendimento orteguiano de vida, optou-se por acompanhar a caracterização construída pelo pensador, ao longo de sua trajetória intelectual. Nesse sentido, as obras Qué és filosofía? e Unas lecciones de metafísica representam o ponto culminante, embora não exclusivo, dessa reflexão, porque, nesses livros, o problema da vida é inserido na grande tradição filosófica do ocidente. Na verdade, boa parte dos textos elaborados a partir dos anos trinta revela a compreensáo metafísica da vida. A tipificação fica mais densa e o filósofo precisa aspectos do problema investigado durante décadas. Os dois livros mostram a interpretação orteguiana da história da Metafísica. Dessa forma, ao lado de sua meditação clara e criativa acerca da vida, manifesta-se o conhecimento do professor de Metafísica, cujas lições apresentam a procura histórica da verdade como a formação de crenças que dão serenidade. A realidade radical buscada na história da filosofia se concretiza em teorias que integram a circunstância das diferentes geraçóes. A interpretaçáo orteguiana da história da Metafísica propóe um ideal de aperfeiçoamento da consciência expresso em formulaçóes que, se não são completas, podem ser menos incompletas com as sucessivas reconstruçóes.

29. A caracterizaçấo da vida tornou-se, em nosso tempo, um problema filosófico. Assim é pela insuficiência teórica do idealismo e do realismo, afirma Ortega y Gasset. As duas perspectivas produziram ao longo da história muitas verdades sobre a vida, algumas antagônicas, todas parciais. É pela Filosofia que se busca responder à pergunta radical pelo fundamento e, com ela, alcançar a verdade radical e superar a parcialidade das verdades já formuladas. Como Ortega y Gasset avalia que nenhuma das duas perspectivas resolveu o problema de forma completa, elaborou uma solução que englobou ambas as perspectivas e as superou. Foi o que pretendeu com a caracterizaçáo da vida 
a qual elaborou, no que denominou metafísica da razão vital. Seu projeto é semelhante ao de Edmund Husserl, no final da vida.

CARVALHO, José Mauricio de. Ortega y Gasset: life as metaphysical reality. Trans/Form/ Ação, Marília, v. 38, n. 1, p. 167-186, Jan./Abr., 2015.

\begin{abstract}
In this article, we study the characteristics that the Spanish philosopher Ortega y Gasset attributed to life. We show that the essence of his meditations revolved around the subject. However, the issue gained metaphysical density only in the late $1920 \mathrm{~s}$, when his remarks were inserted into the philosophical tradition of the West. That is when he pointed out the failure of realism and idealism in the approach to foundations pretended by philosophy, and presented the philosophy of vital reason as a step forward from the two great philosophical perspectives that have marked the history of metaphysics .
\end{abstract}

KEYWORDS: Life. Metaphysics. Characteristics. Reality. Circumstance.

\title{
REFERÊNCIAS
}

AMOEDO, Margarida Isaura Almeida. José Ortega y Gasset, a aventura filosófica da educação. Lisboa: Imprensa Nacional/Casa da Moeda, 2002.

CARPINTERO, Helio. Julián Marías y la metafísica orteguiana. Revista de Estudios Orteguianos, Madrid, p.12-13, 2006.

CARVALHO, José Maurício de. Liçôes de Ortega sobre a vida humana. Ética e Filosofia Politica, Juiz de Fora, v. 1, n. 1, p. 81-90, jul./dez. 1996.

. História da filosofia e tradiçôes culturais. Porto Alegre: EDIPUCRS, 2001. . Introdução à filosofia da razão vital. Londrina: CEFIL, 2002.

. O conceito de circunstância em Ortega y Gasset. Ciências Humanas, Florianópolis, v. 43, n. 2, p.331-345, out. 2009.

. A problemática ética em El Espectador de Ortega y Gasset. Éthic@. Florianópolis, v. 9, n, 1, p.111-125, jun. 2010.

. O século XX em El Espectador de Ortega y Gasset: a crise como desvio moral. Argumentos, Fortaleza, v. 2, n. 4, p.9-18, jun./dez. 2010.

GARAUDY, Roger. Perspectivas do homem. Rio de Janeiro: Civilização Brasileira, 1966.

JASPERS, Karl. Iniciação filosófica. Lisboa: Guimarães, 1987.

KUJAWSKI, Gilberto. Viver é perigoso. São Paulo: GDR, 1986. 
. Ortega y Gasset, a aventura da razão. São Paulo: Moderna, 1994.

LIPOVETSKY, Pilles; SERROY, Jean. A cultura mundo: resposta a uma sociedade desorientada. Sáo Paulo: Companhia das Letras, 2011.

MARÍAS, Julián. Acerca de Ortega. Madrid: Espasa Calpe, 1991.

. História da filosofia. São Paulo: Martins Fontes, 2004.

MINDÁN, Manuel. Principios de metafísica según la razón vital. Revista de Estudios Orteguianos, Madrid, Fundación Ortega y Gasset, v. 19, p.193-204, 2009.

ORTEGA Y GASSET, José. El tema de nuestro tiempo. In: . Obras Completas. Madrid: Alianza, 1994a. v. 3.

. Pidiendo un Goethe desde dentro. In: . Obras Completas. Madrid: Alianza, 1994b. v. 4.

. En torno a Galileo. In: . Obras Completas. Madrid: Alianza, 1994c. v. 5.

. La idea de principio en Leibniz y la evolución de la teoría deductiva. In:

Obras Completas. Madrid: Alianza, 1994d. v. 8.

. Discursos. In: . Obras Completas. Madrid: Alianza, 1994e. v. 11.

. Idea del teatro. In: . Obras Completas. Madrid: Alianza, 1997a. v. 7.

- ¿Qué és filosofía? In: . Obras Completas. Madrid: Alianza, 1997b. v. 7.

. Unas lecciones de metafísica. In: - Obras Completas. Madrid: Alianza, 1997c. v. 12.

. El Quijote en la escuela. In: . Obras Completas. Madrid: Alianza, 1998a. v. 2.

. Ideas sobre Pio Baroja. In: . Obras Completas. Madrid: Alianza, 1998b. v. 2. . Intimidades. In: . Obras Completas. Madrid: Alianza, 1998c. v. 2.

. Elogio del murciélago. In: . Obras Completas. Madrid: Alianza, 1998d. v. 2.

Recebido em: 19/08/14

Aceito em: 12/11/14 
CARVALHO, J. M. 